\title{
UNDERSTANDING OF THE BATIK LAWEYAN SOLO CREATOR FOR COPYRIGHT (STUDY OF LAW NUMBER 28 OF 2014 CONCERNING COPYRIGHT)
}

\author{
Chandra Adi Mauli \\ Sebelas Maret University \\ chandragendoeng@gmail.com
}

\begin{abstract}
The focus of the discussion in this study is the First Copyright Law as an embodiment of penetration of the legal culture of Western (capitalist) countries with individualistic nuances as positive law. Secondly, the culture of the laws of the local community where the Copyright Law is applied as a living law in society (Living law). The purpose of this paper is to know and explain not the implementation of the law as a positive law (positive law) in this case what is meant is the Copyright Act, in an Indonesian society and the Batik Laweyan craftsmen in particular, so that it is expected to explain why Copyright Law cannot function optimally in Indonesia which is marked by the many violations or piracy of a copyrighted work. The method in this writing is a qualitative method with the Sociological Research approach, while the paradigm used as the basis is the Paradigm of Social Definition with the aim of understanding social behavior through interpretation by explaining the path of development and its consequences according to its causes. Based on the social definition paradigm, the theory used is interactionism theory, which mainly emphasizes sociopsychological perspectives, the main goal of which is the individual in his personal personality and the interaction between internal opinion and one's emotions with social behavior. With the Symbolic Interaction Theory approach, in this study will be able to further reveal the behavior of certain community groups by interacting with existing social behavior. And also with the Phenomenology Theory is that human action becomes a social relationship if humans give a certain meaning or meaning to their actions, and other human beings also understand their actions as appropriate which means that humans are social beings, so that the awareness of daily life is an absolute magnification. As for the study findings it turns out, the Copyright Act in the application in the Laweyan Batik Craftsman community is in conflict with the Javanese legal culture that promotes harmony between neighbors, ewuhpekeweuh, tepasliro, mutual cooperation. If the law of copyright is strictly enforced, it will result in disturbance of neighborly living conditions. Because most Batik Laweyan craftsmen live next to each other even there is still a kinship, so that when it comes to demanding or monopolizing a work, it will lead to neighboring reluctance. They assume that even the art of batik is their property from the property of their ancestors so that anyone can imitate and make it.
\end{abstract}

Keywords: Copyright; Batik Craftsmen

\section{Introduction}

With the ratification of the world trade agreement and tariff rationalization carried out in the GATT (General Agrement on Tariffs and Trade) which is a multilateral trade agreement in the Uruguay round (1986) which succeeded in forming the WTO (World Trade Organization) which began in January 1995.The Uruguay round of GATT negotiations included, among others, an agreement on Trade Aspects of Intellectual Property Rights (Agrement on Trade Related Aspects of Property Intellectual Property Including Trade Advantage Goods (TRIPs). The export aspect of Laweyan's Batik handicrafts of course must get adequate protection from Law No. 28 
of 2014 Copyright (UUHC), so that there needs to be a change in the mindset of the small craftsmen's society towards the copyright registration of their creations, because of the late piracy this end tends to be at an alarming level, even the robbery of works of small craftsmen by big businessmen has occurred.

Regarding copyright beforehand has been arranged long before the independence of the State of Indonesia which is regulated in Autonomy 1912 (Stb. 1912 No. 600). The concept of copyright law has been applied several times in Indonesia in the positive legal regulations in Indonesia namely 1958, 1966 and 1971. The draft Law Number 28 of 2014 concerning copyright in its consideration stated the reasons used to make changes to the 1912 Autonomy included:

a. That there have been voices in the community which indicate that there is a less satisfying fate between the creator and those who use the creation;

b. The absence of an agency or organization fighting for the rights of the creator, and

c. The regulations that apply to copyright are not well known ${ }^{1}$

It is undeniable that the regulation and implementation of protection against copyright cannot be separated from the pressure and needs of the developed countries to protect their creation rights outside their country, although in addition it tucked a little national interest to regulate the concept of copyright law into the legislative system -national legislation is to protect the copyright, especially the craftsmen of folk handicrafts and legal certainty of domestic creations that are not comparable in number compared to foreign works. If we take a look at the regulation on special intellectual property rights on copyright in the past 20 years there have been four changes, although under the pretext of improving the copyright law but the real reason is the pressure from developed countries namely the threat from developed countries about revocation Generalized System of Preferences (GSP). With the emergence of world organizations and the demands of world countries through the World Trade Organization (WTO) and the General Agreement on Tariffs and Trade (GATT) so that intellectual property rights have adequate arrangements in national legislation for the country countries that ratify the Agreement Establishing the World Trade Organization, so that the copyright regulation undergoes several changes and improvements to each: Law no. 6 of 1982 concerning Copyright (1982 State Gazette No. 15 and Additional State Gazette No. 3217), Law No. 7 of 1987 concerning Amendments to Law No. 6 of 1982 concerning Copyright (1982 State

\footnotetext{
${ }^{1}$ Sophar Maru Hutagalung, Hak Cipta, Kedudukan Dan Peranannya Dalam Pembangunan (Jakarta: Akademika Pressindo, 1996), 102.
} 
Gazette No. 3362 and Supplement to the State Gazette No. 3362) and Law No. 12 of 1997 concerning Amendments to Law No. 6 of 1982 concerning Copyright as amended by Law No. 7 of 1987 (State Gazette of 1997 No. 2 and Supplement to the State Gazette No. 3679). Last is Law Number 28 of 2014 concerning Copyright.

The increasingly global economic development, including products protected by copyright, where a country's products are often traded in other countries, has led to the importance of legal sources of agreement between countries. Agreement between countries is necessary because each sovereign country has its laws individually. Foreign law does not apply within a sovereign state, and vice versa. In order to regulate trade that crosses national boundaries, an agreement between countries is needed, if bilateral (two countries) and if multilateral (many countries). Both bilateral and multilateral agreements usually do not apply directly to the people in the participating countries.Research conducted by the Indonesian government both multilaterally and bilaterally aims to increase protection of intellectual property rights (IPR) from traded products, regarding procedures for the implementation of IPRs (especially copyrights) that do not inhibit trade activities, formulate rules and discipline to recognize the implementation of protection trade Intellectual Property Rights, and develop principles of rules and mechanisms for international activities to handle the trade in IPR products ${ }^{2}$.

As the writer said above, the IPR protection system is a value from a western country, perhaps its implementation is not like the legal concept, it also conducts trade in certain communities that reject copyright protection as expressed by I KetutWirawan, that imitates the work art is so open and there is even a kind of pride for a creator (art work) if his work can be copied or copied by others in the future and benefits for that person (the person who imitates). For such creators there is at least an assumption that he has done good for the Welfare among his fellowmen as required by the teachings of Hinduism ${ }^{3}$.

Similarly, what was expressed in Dewi Kasih's research that the process of imitating the imitation of art in Bali came from the method of teaching art in the Balinese artists themselves who relied on the method of imitation in the learning process, where the teachers transmitted an artwork through examples directly and the students imitated directly too. Besides that, there are quite a lot of researches on making skills, works of art are self-taught, that is only through sight

\footnotetext{
${ }^{2}$ A Zen Oemar Purba, "Principles of Development Policy for National Intellectual Property Systems," in Prospect and Implementation of Indonesian Copyright, Patent and Trademark Laws (Jakarta, 2001).

${ }^{3}$ I Ketut Wirawan, "Budaya Hukum Dan Disfungsi Undang-Undang Hak Cipta: Kasus Masyarakat Seniman Bali" (Universitas Diponegoro, 2000), 26.
} 
(only by looking and then trying to make) and one can easily create an artwork similar to the original work. In such a situation, Balinese artists in general and in particular the teachers and creators are only art not thinking economically, but rather proud of being able to preserve their abilities and more fundamentally that they feel they can help others. ${ }^{4}$

Western thought of copyright, that copyright is the property of individuals embraced by most Indonesian people, especially the creators without leaving the rights to the community. Rona Rosita said, in the results of her research the things that encourage copyright infringement.

Matters that encourage copyright infringement by the community, among others. Copyright infringement activities are influenced by various factors, including in general are:

1. Low level of public understanding of the meaning and function of copyright.

2. Attitude or desire to gain trade benefits with caramudah.

3. There is not enough awareness about the understanding, attitudes and actions of law enforcement officials in the face of copyright infringement.

In addition to the above, copyright infringement is influenced by factors specifically, including:

1. Economic factors

a. In general, the price of illegal products is cheaper than legal / original, so consumers, especially the middle to lower classes, tend to prefer to buy cheap products, especially if it seems not too much different, where this is clearly very influential on the increasing marketing of illegal products. .

b. The perpetrators of crime or copyright benefit a lot because they do not need to pay royalties to the copyright holder whose product is duplicated.

c. Products resulting from copyright crimes are generally produced illegally, thus avoiding tax payments that should be paid.

\section{Social factors}

a. The rapid development of science and technology has influenced various possibilities and ease of committing crime or in the field of copyright.

b. The high unemployment rate and the limited time to get a job, encourage some citizens to try to do anything including work related to copyright crimes, for example: selling pirated computer programs.

\footnotetext{
${ }^{4}$ Desah Putuh Dewi Kasih, Laporan Penelitian Pelaksanaan Peregangan Statik 29 UU No. 7 Tahun 1987 Sebagai Pelindung Hak Cipta Benda-Benda Seni Di Desa Kemanuk Kecamatan Sukowati Giayar (Bali, 1992), 54.
} 
c. Weak purchasing power of the people is faced with the need for certain products, encouraging increased marketing of illegal products in the field of copyright at affordable prices even with low quality.

d. The uneven distribution of copyright issues in the community will require respect for the work of others.

3. Cultural factors 5

The ordinary people live in togetherness and have differences with very individual IPRs which means that many of the things that underlie the provision of copyright law protection to copyright holders comes from the individualistic cultural values of Western societies that seek to give exclusive rights to individuals over rights its wealth, while in Indonesia its cultural values are still quite high so that its rights are often associated with the social function of the community ${ }^{6}$

Starting from the aforementioned factors, of course many small craftsmen do not understand the existence of copyright laws, they only think of producing an item and then being sold in the community. The legal culture of the community is different from each other, as exemplified above, the Balinese Hindu community does not need copyright protection, the business community in Jakarta glorifies copyright protection. Public perception of copyright differs. If copyright infringement is deemed not to be a threat, it is even a charity.Copyright which has been regulated in a law is a norm, that copyright infringement is a criminal offense. Such norms will clash with the legal culture of certain community units, or even clash with public ignorance of copyright protection; so whether or not the legislation is accepted by the community is in accordance with or not with the legal culture of a society. As expressed by Lawrence M Friedmansaid that legal culture is the whole of the general public attitudes and values, in society that will determine how the law should apply in society. Thus the legal culture occupies a very strategic position in determining the choice to behave in accepting the law or vice versa (refusing). Legal institution will eventually become a law that is truly accepted and used by the community or a particular community is largely determined by the legal culture of the community or the community concerned.(Article 29 and Article 5 of the Copyright Act It is important to note that the copyright is regulated in three Laws No. 6 of 1982 concerning

\footnotetext{
${ }^{5}$ Rona Rositawati, "Perlindungan Hukum Terhadap Pemegang Hak Cipta Program Komputer Menurut UndangUndang Hak Cipta" (Universitas Negeri Sebelas Maret, 2001), 15.

${ }^{6}$ Wirawan, "Budaya Hukum Dan Disfungsi Undang-Undang Hak Cipta: Kasus Masyarakat Seniman Bali," 104.
} 
Copyright in Amandernen with Law No. 7 of 1987 and in accordance with Law No. 12 of 1997 and the latest Law No.28 Th.2014.)

In the perspective of the batik craftsman community in Laweyan Solo, the copyright law really needs to be empowered both for craftsmen, business people and law enforcement officials. From preliminary research it was found that large entrepreneurs hijacked by buying products from Laweyan Solo batik craftsmen, who were then registered at the Directorate of Copyright, Patents and Brands as the copyright holders. Here it is seen that the law is used as a tool to manipulate the creation of others.

The basic assumption of the Laweyan batik craftsmen is the creation of a work is part of their traditional way of working, so the existence of copyright law is a necessity, even though they cannot use it fully. They don't or rarely register their creations. Although the copyright law does not require the registration of a work, the registration of the work is needed because it is an authentic proof of a new copyright so that the ownership of a right, so that when a dispute later occurs in court, the copyright certificate can be used as a tool proof. To obtain the certificate the creator must register his work addressed to the Minister of Justice through the Copyright Director of the Directorate of Copyright, Patents and Brands (I KetutWirawan Op. Cit. Page 136)

In connection with the above matter, the implementation of the Copyright Law on handicraft craftsmen (small craftsmen) should be carried out continuously by the government so that their protection is expected to be perfectly covered by piracy Unlike the Balinese Hindu community, creation their artwork is based on Dharma (religion) which aims to attain Makso (eternal happiness), but in the society of batik craftsmen in Laweyan Solo the aim of creating batik art is merely an economic factor. That is why the assumption of creation is exclusive the creator is an absolute necessity for them, it's just that their way of thinking and understanding of copyright is not fully understood by them, even though the work of batik craftsmen in Laweyan Solo is an export potential.

\section{Research Methods}

\subsection{Approach Method}

In this study the approach method is phenomenological, because in this study law is a social phenomenon to find the meaning behind the existing social factors. Also sociological juridical because besides legal phenomena as social phenomena, also sociological because the object of research is a particular social community related to respondents Laweyan Solo batik 
craftsmen.Qualitative methods allow us to understand society personally and look at them as they express their world views. With a socio-legal approach, the law is not only seen as a rule or just rules but also includes how the law works in society and how the law interacts with this environment Copyright laws are expected to protect the creation of batik craftsmen in Laweyan because they consist from people who don't know Law. ${ }^{7}$

\subsection{Nature of Research}

From the data and nature of this research is an analytical descriptive research which is a study that seeks to describe in detail the social phenomena that are the subject matter without conducting a hypothesis and statistical calculations. Facts relating to legal reasons or culture of a copyright registration, will be analyzed in order to get an overview of the legal culture of small craftsmen, especially batik craftsmen in Laweyan Solo for registration and understanding of copyright.

\subsection{Research location}

This research was carried out at LaweyanSolo. The choice of the location in addition to being the center of the industrial batik handicraft of the people is also an export potential, the majority of the local population is of Javanese descent.

\subsection{Types of Data Sources}

The type of data used in this study is primary data and secondary data. Primary data is data obtained directly from the field from the research location (Field Research) which in this case includes behavior, perceptions of Juana small brass craftsmen for copyright registration. Secondary data is data that supports primary data that can come from literature, books, previous research, magazines, newspapers, brochures related to the problems faced.

\subsection{Informants}

Determination of informants is done with a positive sampling method adjusted to the interests and needs in analyzing the development of information and the source is done by SnowBall (snowball) to reach the point of saturation in the sense that the completeness and validation of information is sufficient for the sake of analyzing.

Information in this study was taken from various parties, namely:

a. Batik craftsmen at Laweyan Solo who created batik handicraft products.

b. The batik company in Laweyan Solo accommodates and produces batik crafts.

c. Business actors, craftsmen who have had problems with their copyright piracy

\footnotetext{
${ }^{7}$ Esmi Warassih Pudjirahaju, Metode Penelitian Bidang Ilmu Humanoria Metodologi Penelitian Ilmu Sosial Orientasi Penelitian Bidang Hukum (Semarang: FH UNDIP, 1994), 47.
} 
d. The subdistrict village apparatus, Laweyan Solo related.

\subsection{Data Collection Techniques}

The collection of research data is carried out in two ways, namely:

1. Interviews (interview) and

2. Participatory observations (Participant Observations).

The interviews in this study were taken first of all in a non-directive interview that was not based on a list of questions that had been prepared beforehand. The researcher tried to obtain information from the informant without giving sharp directions, but it was up to the informants interviewed in accordance with their abilities and willingness. Then continued the in-depth interview (indept interview) is expected to share more in-depth information about the object of research observed in the field.

\subsection{Research Instruments}

The tools / instruments used to support data collection in this study are:
a. Humans or researchers themselves
b. Notes
c. Photo
d. Tape recorder

\subsection{Data Analysis}

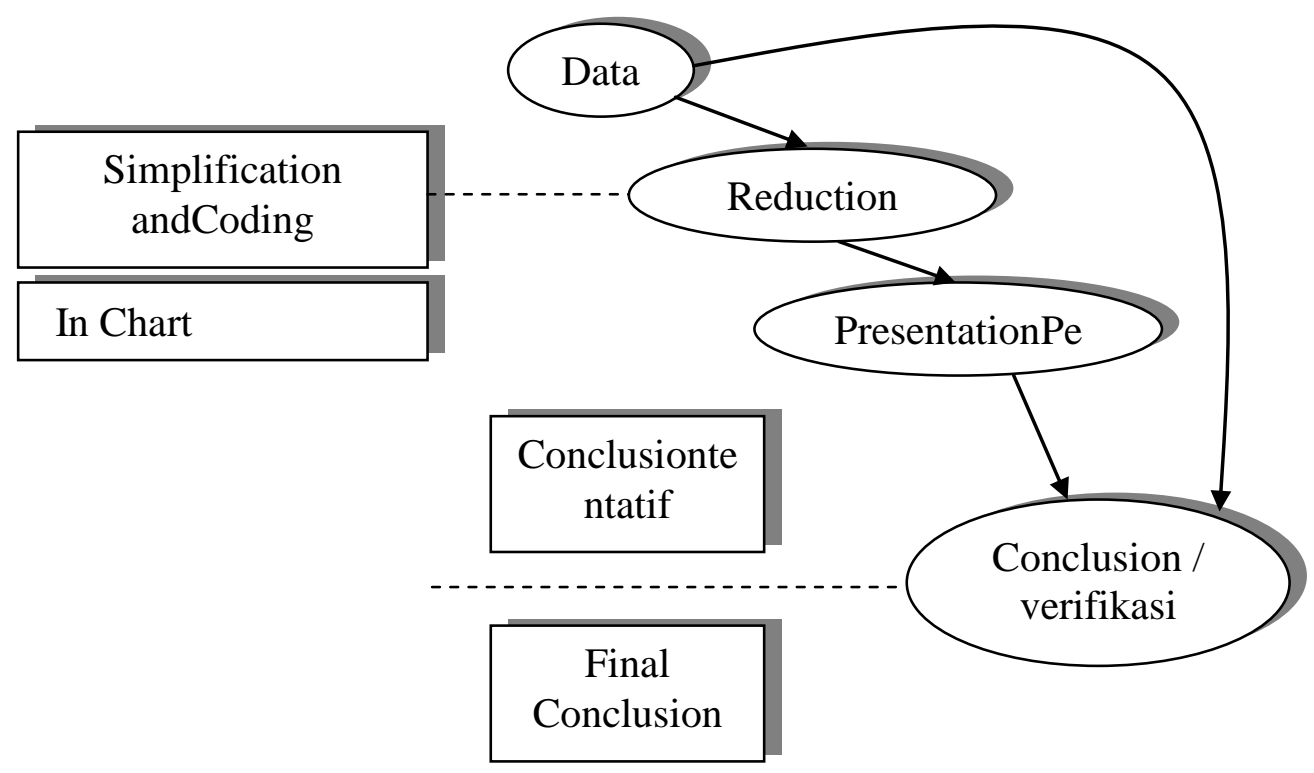


To process data or data analysis that has been considered valid or reliable that relies on constructing data through strategies or approaches that rely on the conceptualist-induced logic of thinking (conceptualization induction) on the one hand and the logic of emic thinking on the other. The logic of thinking is the impact of conceptualism, the researcher will construct all empirical facts to develop concepts, hypotheses and theory development. Whereas through emic logic is done to understand the relationship between various cultural interpretations and traditions of the community. ${ }^{8}$

Because it is a cycle and interactive process, the activity of data reduction, data presentation and conclusion or verification is carried out continuously so that the data obtained is no longer volatile or permanent. The meaning is that as long as the meanings arising from data that are not yet valid and reliable indicated by truth, their robustness and suitability during conclusions are not yet a complete configuration, through the three lines of analysis above they are continuously implemented both in terms of emic analysis and the purpose of ethical interpretation Activity cycle scheme in the process of analyzing research data is as follows:

To get data that is truly valid with a degree of confidence level of confidence or credibility in several ways, namely:

1. Extension of participation, which will allow increased confidence in the data collected so as to reduce the validity of the data caused by distortions originating from the subject or from the researcher or respondent.

2. Perseverance of observation

Perseverance of observation intends to find the characteristics and elements in situations that are very relevant to the problem or issue that is being sought and then focus on these things in detail, so that the depth of data can be applied. ${ }^{9}$

\section{Discussion}

Under the copyright law (Law No. 6 of 1982, Law No. 7 of 1987, Law No. 12 of 1997, Law Number 19 of 2012 and finally Law Number 28 of the Year 2014 concerning Copyright) which regulates copyright registration adheres to a declarative system that is only announced in the public at large has given birth to copyright. So without registration in the General of Copyright and Patents, the copyright can already be owned by the creator of reality as this often

\footnotetext{
${ }^{8}$ Lexy J. Moleong, Metode Penelitian Kualitatif (Bandung: Remaja Rosdakarya, 1997), 165.

${ }^{9}$ HB Sutopo, Pengantar Penelitian Kualitatif: Dasar-Dasar Teoritis Dan Praktis (Surakarta: Pusat Penelitian UNS, 1988), 37.
} 
leads to piracy rights copyright and create disputes over who owns the creation first. This is because there is no official data stating who is the first or who owns the creation.

In reality on the ground that occurred in the center of Laweyan's batik craft industry, Laweyan's batik creation was hijacked which was then registered in the Copyright and Patent General, so that the copyright is authentic to the hijacker, so the craftsmen are no longer allowed to produce Laweyan batik. This creates injustice for Laweyan batik craftsmen, because Laweyan batik creations have been handed down from generation to generation. However, the Laweyan batik craftsmen did not register copyright to the Copyright and Patent offices. This may have two reasons which caused them not to register their creations, among others, encouraged by their ignorance of the registration of Copyright, so that problems arose how to synchronize the implementation of Copyright Law with the culture of the local community.

In addition to the foregoing, the majority of people in Laweyan batik village are Javanese. The nature and life of the manganese people, oramangannekkumpul (eating does not eat as long as they gather), Nek onodinggo together with podhoentuk (If there is a joint use, together can) and many more Javanese philosophies that background their indifference to a Copyright Law.

Research question. Of the two cultures that collide, of course, will cause one culture to stop and another culture to live. Or two cultures are living side by side. Or there is a rejection of foreign culture in an area. Foreign culture referred to here is the individualization of a work invention that was adopted from western culture confirmed in the Copyright Act, while the Javanese community in general and people in the village of Batik Laweyan in particular see a work of batik craft as a communal, hereditary property. So that anyone can imitate the origin of being able to make. Of the two cultures that collide it will raise research questions, among others: How is the perception of .Laweyan's batik craftsmen against piracy / imitation Copyright? From the formulation of the above-mentioned problem in general, this study aims to identify and explain a community that (especially the craftsmen in Laweyan's batik village against a law that concerns the interests of laws and regulations that are not addressed optimally by them In the interest of this, it is hoped that this research will put the effectiveness of laws and regulations, especially the Copyright Law on Laweyan batik craftsmen.

Based on the findings both in writing and field findings that the implementation of the Copyright Law in general cannot be implemented as expected by the makers of the Law, especially the implementation in the Batik Laweyan craftsmen community, among others, the 
following matters: Regarding the Copyright Law, especially in the community, Laweyan Batik craftsmen almost do not need the protection of copyrighted works that are regulated in the Copyright Law. The regulation on copyright is not a basic need in producing or developing a batik craft. The existence of more Copyright Laws at government initiatives and foreign deposits. The existence of the Copyright Law in its implementation collides with the culture of the local community. Javanese culture more dominates the non-functioning of the copyright law. Javanese culture is caring (reluctant) in demanding a right with one's own neighbor. So that the placement of copyright is almost never done. Community understanding of copyright is very low, even people often ignore, this is due to copyright is something of western culture and not an aspiration of the people below, this is of course a lot of unintentional copyright violations due to lack of public knowledge of the rights law create.

The understanding of the Laweyan Batik craftsmen community on the registration of copyrighted works and the copyright monopoly has never been done at all. This is because the copyright does not require the registration of copyrighted works as well as the craftsman's knowledge is minimal. Also in addition to the legal culture, the craftsmen assume that copyright belongs to the people, the important thing is how to produce, how to market handicraft products. So the monopoly of a copyrighted work belongs to the people, the important thing is how to produce, how to market handicraft products. So the monopoly of a copyrighted work is not the intention and purpose to get an economic value. Producing with good quality and maintaining market share is more important than monopolizing a copyrighted work. The ability of Batik Laweyan craftsmen to register is very long-winded and considered useless. The culture of monopolizing a copyrighted work is not a habit of Laweyan Batik craftsmen. Some of the Javanese proverbial phrases that underlie this are tiyangpunika, which is the nahthah (the person must accept his existence), the sintering is not damning, the syntax of the nanem download (the one who produces it will eat it, and the person who plants it will reap the rewards), teposeliro (tolerance), courageous (reluctant to others).

The application of the Copyright Law in the Batik Laweyan craftsmen community is strongly influenced by the local legal culture or local cultural values. The life of the Batik Laweyan craftsmen is strongly influenced by the village culture where Laweyan village is located. Mutual cooperation, splice (helping neighbors voluntarily, jagong (event) is the values that underlie the behavior of the people of Batik Laweyan craftsmen towards neighboring pillars is more important than maintaining or monopolizing a copyright. Jawi Religion values that teach 
that God is the Creator who is the cause of all the life of the world and the entire universe. Giving charity is a matter taught by religion. Giving the opportunity of creative works to earn a living is alms, when creating harmony of neighbors.

\section{Conclusion}

The response of the Laweyan Batik craftsmen community is negative, this is shown by the low understanding of the public about the presence of the Copyright Act. Copyright is an abstract right that is not seen by the eyes, even though the culture of Indonesian people appreciates concrete things such as culture in customary law, the people who practice Laweyan Batik are more obedient to brand rights than copyright, because brand rights are concrete rights that can be seen by the eyes and greetings the owner, so that until now there has never been a dispute over copyright issues or the registration of copyrighted works by Laweyan Batik craftsmen, besides Javanese culture dominates the background of the life of Laweyan Batik craftsmen

\section{Suggestions}

For protection of copyrighted works, copyright laws should be applied wisely, given that the public is not yet familiar with the existence of copyright laws, besides the legal culture of the Indonesian people in general and Laweyan Batik craftsmen are apathetic towards the entry into force of the copyright law.

It is expected that there will be a continuous and gradual socialization of the Copyright Law, given that changing a legal culture of a society requires a lot of time. This needs to be done considering that Indonesia has entered the global market dominated by the capitalist state, our society must be prepared to become innovative craftsmen who like to create new things, so that they have competitiveness in the global market.

For each Regional Government, in particular the Government of Surakarta City Government is expected to continuously carry out coaching, counseling, especially on the registration of a copyrighted work because copyrighted works in the field of folk crafts are regional assets in the current era of regional autonomy. 


\section{References}

Hutagalung, Sophar Maru. Hak Cipta, Kedudukan Dan Peranannya Dalam Pembangunan. Jakarta: Akademika Pressindo, 1996.

Kasih, Desah Putuh Dewi. Laporan Penelitian Pelaksanaan Peregangan Statik 29 UU No. 7 Tahun 1987 Sebagai Pelindung Hak Cipta Benda-Benda Seni Di Desa Kemanuk Kecamatan Sukowati Giayar. Bali, 1992.

Moleong, Lexy J. Metode Penelitian Kualitatif. Bandung: Remaja Rosdakarya, 1997.

Pudjirahaju, Esmi Warassih. Metode Penelitian Bidang Ilmu Humanoria Metodologi Penelitian Ilmu Sosial Orientasi Penelitian Bidang Hukum. Semarang: FH UNDIP, 1994.

Purba, A Zen Oemar. "Principles of Development Policy for National Intellectual Property Systems." In Prospect and Implementation of Indonesian Copyright, Patent and Trademark Laws. Jakarta, 2001.

Rositawati, Rona. "Perlindungan Hukum Terhadap Pemegang Hak Cipta Program Komputer Menurut Undang-Undang Hak Cipta.” Universitas Negeri Sebelas Maret, 2001.

Sutopo, HB. Pengantar Penelitian Kualitatif: Dasar-Dasar Teoritis Dan Praktis. Surakarta: Pusat Penelitian UNS, 1988.

Wirawan, I Ketut. "Budaya Hukum Dan Disfungsi Undang-Undang Hak Cipta: Kasus Masyarakat Seniman Bali.” Universitas Diponegoro, 2000. 